\title{
A Feminist-Based Studio Art Critique: A Classroom Study
}

\section{Anne Burkhart}

\section{Introduction}

Many art educators (e.g., Congdon, 1991; Garber, 1992a, 1992b, 1990. Hagaman, 1990; Hamblen, 1986; Nadaner, 1984) strongly advocate that art should be understood in relation to its sociopolitical meanings and ideological bases. Hamblen (ibid.) cites the need for further development of sociopolitically focused theoretical bases for art criticism in art education, as well as frameworks for incorporating them into pedagogy.

Feminist art educators are among the most vocal proponents of understanding art in relation to its sociopolitical meanings and ideological underpinnings. Garber (1990) suggests that feminist art criticism can function as an exemplar for art criticism because of the variety of views within feminism and because of its respect for diversity. Feminist research in art education (e.g., Garber 1992a, 1992b, 1990) has begun to explore and articulate feminist theories and make implications for classroom applications.

I have long been interested in criticism, feminism, studio art critiques, and feminist art criticism. Hennessey (1993) states that "the myriad forms of violence against women, the persistent worldwide devaluation of femininity and women's work, and the intensified controls over women's sexuality and reproductive capacities are daily reminders of the need for a strong and persistent feminist movement" (p. xi). I concur with feminists who locate "gender as a dynamic element in all human experiences" (Garber, 1990, p. 20), and consider myself to be a feminist. I believe that feminist theories, among others, can help articulate frameworks for understanding how intersecting systems of oppression function and can offer suggestions for change.

As Garber (1990) states, the need is as great in art classrooms as it is anywhere else for students to explore the mechanisms of patriarchy and its interaction with other systemic oppressive practices, such as those pertaining to race, class, ethnicity, sexual orientation, and other factors. Representations, including those that commonly fall into the category "art" are an important cultural products that contribute to social understandings

Criticism is a process that is connected to understandings which can potentially affect social change (Garber 1992a; Pollock, 1987; Nadaner, 1984). The studio critique can contribute to sociopolitical art understandings which can affect social change, although studio inquiry does not typically do this (see Barrett, 1994). Constructions of feminist theories of art criticism and their implications for pedagogical structures fundamental to the art classroom, such as the studio critique, are needed to aid in making feminist art education a tangible practice.

Marilyn Zurmuehlen's Working Papers In Art Education 1996-1997 


\section{Statement of the Problem}

This study emerged from my interests in making, thinking, and writing critically about art, and in leaching others these same activities. As a studio artist, I remember the kinds of critiques I experienced that are also typical of many studio art classes. These critiques consist of a one-way exchange of information in which the instructor mostly offers the students advice on how to improve their artworks. A studio art critique is an organized session in which student artworks are viewed by both the class and the instructor, and in which students are supposed to learn something about the art being critiqued. Studio art critiques are typically conducted solely by the instructor.

During the introductory photography course I taught as a graduate teaching assistant, not only did students often demonstrate a lack of interest in and knowledge of how to explore underlying ideologies and sociopolitical implications of artworks during studio art critiques, they also displayed a general resistance to describing and interpreting images in general. I structured critical activities, and had some success in engaging students in critical dialogue, mostly about artworks that I presented as exemplars. Even atter being introduced to some sociopolitically-focused ideas, including many feminist ones, and after discussions in which students voluntarily incorporated feminist or other sociopolitically-focused ideas in classroom discussions about artworks used as exemplars, students rarely demonstrated an interest in or understanding of incorporating these concepts in studio art critiques.

During studio art critiques, I noticed that despite my attempts to encourage interpretive discussions, particularly those which led to investigations of the sociopolitical meanings of some photographs, students often seemed the most interested in the kind of critical attention that they were used to receiving in other studio classes or thought they should receive during critiques. This critical attention centered around technical information that focused on how to make better pictures. Among the ideologies and implications that students seemed apathetic toward include knowledge of and sensitivity to feminist issues about representation. A lack of understanding and interest in these or other sociopolitically-focused ideas was reflected in students' discussions and critical writings. A number of reasons may have contributed to students' failure give consideration to sociopolitical concerns during critiques. Some of the possible reasons include attitudes and beliefs about both ferninism and other sociopolitical concerns, and about studio art critiques. For instance, some students may not be interested in sociopolitical art understandings including ferninist ones: some may have biased or limited ideas about ferninism; some may be anti-ferninist; some may not feel comfortable voicing their ideas; some may not have adequate strategies for investigating sociopolitical art understandings which would enable them to meaningfully use them during studio critiques; some may have preconceptions about the studio art critique that impair their willingness to engage in critiques that do not conform to their expectations. The latter point refers to a study by Barrett (1988) which determined that art education students conduct studio critiques similar to the way their studio professors conducted them, contrary to what they may have learned in art education classes in criticism. 


\section{Statement of the Problem}

Garber (1990) and Barrett (1988) state that in art education, criticism usually results in an examination of the formal properties of works of art. Bright (1988) states that students' expectations in introductory photography courses center around technical proficiency, taking better pictures, and learning to succeed in the art world, not around developing a critical consciousness of the images that they make.

I perceive the need for a structured approach to conducting studio art critiques that both provides conceptual tools for and that encourages sociopolitical art understandings. I wanted to structure a way to help students to think not only about relevant technical information, but to help them think interpretively, and, to help provide conceptual tools for and to encourage examining the sociopolitical meanings of artworks during critiques. I believe that feminist theories are among those that can provide a rich core of ideas with which to structure such a critique because feminism has evolved into a complex range of sociopolitically-focused ideas.

Many questions guide this study. What is feminism? How can I use feminist theories to address art making in the context of the studio art critique? What might a feminist studio art critique be like? How would students react? Primarily I wanted to know whether feminist theories can influence studio art critiques in ways that significantly contribute to students' sociopolitical art understandings. I constructed a set of guiding ideas derived from feminist theories and applied them to the studio art critique.

\section{Theoretical Frameworks}

I began to look to various theoretical frameworks, and was already somewhat familiar with feminism and consider myself to be a feminist. Upon exploring feminism at length, I decided to cull ideas primarily from various feminist theories to help structure guidelines for a studio art critique.

There are several reasons why I believe that many feminist ideas lend themselves to help structure the guiding ideas for this critique. Feminist theories are by nature sociopolitically-focused. Feminist theories start with ideas about inequitable societal conditions concerning women and others. and seek ways to understand and improve those conditions.

There are many feminisms, making it a rich theoretical field with a long history from which to draw (see Tong, 1989; Humm, 1992; Jaggar, 1988). It is impossible to sum up major feminist frameworks in a sentence or two; therefore the following descriptions should be understood to be extremely limited and incomplete as representations of those theories. important feminist frameworks include liberal feminisms, an influential set of ideas with a long history that is mostly concerned with individual rights, and that are embodied by organizations such as the National Organization of Women. 
Marxist and materialist feminisms examine the material conditions of women's lives and examine economic factors in terms of gender. These frameworks focus on the fundamental nature of these factors, and, in varying ways, examine material conditions in terms of gender as determining social existence and therefore as keys to societal change.

Radical feminisms are fundamentally new theoretical frameworks (Jaggar, ibid.) that analyze gender inequality "in which men as a group dominate women as a group and are the main beneficiaries of the subordination of women" (Walby, 1990, p. 3). Radical feminisms analyze patriarchy and examines how sexuality and gender have been used to oppress and subordinate women (Tong, ibid.).

Psychoanalytic feminisms utilize Freudian theory to analyze early stages of gender development. Some theorists focus on childrearing practices including the impact of involvement by the mother and/or father. Some focus on how gender identity is tied to the acquisition of language (Bryson, 1992).

Socialist feminisms "inhabit, critique, and reconstruct" Marxist ideas (Johnson, 1991, p. 355) with ideas from radical feminisms. Socialist feminists believe that class issues as well as gender and its construction play equal roles in women's oppression.

Postmodern feminisms embody the interaction of feminist ideas with groups of ideas commonly called "postmodern" and/or explore feminist ideas as parallel to or postmodern in nature. There are many postmodern feminist ideas. Most critique ideas about the rational subject, exploring how it is constructing in masculine terms (McNay, 1992); and reject universalizing claims, and claims of neutrality. Other theorists (see Tong, ibid.) explore ideas of woman as the Other, celebrate the feminine, of Otherness as a way of being. Dichotomies such as reason/emotion and self/other, the idea of a coherent identity, concepts such as "woman" and "man," and of quests for truth are challenged.

Feminist women of colortwomen of non-dominant groups, have long been discussing different biases of much early academic feminism. In the mid1970 's, the Combahee River Collective started pointing out the importance of intersecting the identity-based constructs of gender, class, race, and sexual orientation (Humm, ibid.).

Feminist standpoint theoriesemerged mostly from materialist and socialist feminisms, and posit that a complex set of intersecting social forces comprise a person's standpoint, or way of seeing and being in the world. These theories are concerned with how social experience shapes reality. Because of the differences in class, race, age, sexuality, and other factors, these intersecting facets of women's identities, there are "multiple feminist standpoints" (Lather, 1942). These theorists also posit that people with marginal facets of identity have a less distorted, more objective perspective on social relations (Harding, 1993).

This list of feminisms is not complete and it should be understood that labels should be used with caution because feminist ideas are continually

Marilyn Zurmuehlen's Working Papers In Art Education 1996-1997 
evolving because of the complexity of feminism (Bryson, ibid.; Tong, ibid.). Many feminisms welcome the tensions within feminism as healthy and positive partially because these tensions resist fixing feminist thought by participating in ongoing self-critical activities (Weed, 1989).

Another reason to draw from feminist theories is to incorporate some directions that are being advocated within the field of art education. Many art educators increasingly articulate the need to welcome and acknowledge diversity in art classrooms. The diversity of and the debates within feminism may serve as exemplar for art educational practices. Garber (1990) has referred to feminisms that in addition to gender, hold parallel concerns for issues involving race, age, ethnicity, ability, sexual orientation and other factors; and she has pointed out that feminist art criticism can function as an exemplar for art criticism because of the variety of views within feminism and because of its respect for diversity.

1 do not feel the necessity, nor would it be possible, to exactly align this project with one category of feminist thought. However, certain strands of feminism influenced the construction of my feminist studio art critique more than other strands. While in many instances they are still important, quests for equality are not necessarily enough or necessarily desirable. However, some directions in liberal feminist are still useful. One example is how the Guerilla Girls raise awareness about gender inequality in the art world through the use of statistical comparisons. While it can be useful and important to investigate the regulatory and restrictive practices of patriarchy, as radical feminists do, other repressive systemic structures should not only be simultaneously investigated, but investigated for the specific ways that they intersect with each other. Understandings about people's lives and the potential for change must consider the material conditions of those lives, particularly as they relate to factors such as gender, race, and class. The social and political dimensions of gender and how gender is constructed should be explored. Thus, feminist standpoint theory has influenced this project, as have some postmodern feminist ideas. The instability and of identity-based constructs such as "women" should be explored, yet the ways in which those constructs are useful should also be explored. Weed states that the terms of feminism are "given to it by the social formations in which it is produced, and feminist practice becomes an ongoing theoretical and political process of re inscribing or dismantling those terms" (ibid., p. xvi).

The guiding feminist ideas that I constructed are as follows. It should be understood that it is the collection of ideas that I consider to be feminist, and not necessarily single ideas.

1. Artworks have "aboutness" and demand interpretation (see Barrett, 1994a).

2. Description can reveal important interpretive clues.

3. Interpretations and the consequences of those interpretations are the most important aspects of critiques (see Barrett, 1994a).

4. Artworks should be examined for their sociopolitical meanings and implications.

5. Concepts about identity can be important in interpreting artworks. 
6. A plurality of interpretations should be encouraged (see Garber, 1990, Congdon, 1991).

7. Students should be encouraged to articulate their feelings about artworks in part because feelings can be clues to non-dominant ideas (see Jaggar, 1988).

8. Acknowledging and exploring the influence of the context of the studio art critique is important.

9. Students should be encouraged to explore criteria used to interpret and evaluate artworks (see Barrett, 1994a).

10. Intentionalist criticism should be encouraged (see Barrett, 1994a).

11. Artists can sometimes be informative resources for their artworks.

12. Instructors should encourage sociopolitical discussions of artworks.

\section{Participants/location of research}

I conducted this action-research based classroom study at a large, midwestern research university during one quarter in an introductory black and white photography class. I had previously taught the course was familiar with photo faculty and graduate students. I worked with an instructor who taught the class but allowed me to conduct the critiques. Photographic assignments that were part of the course were mostly typical of the kind found in introductory photo classes (e.g. documentary, self-portrait).

\section{Components of a feminist studio art critique}

Based mostly on ferninist ideas, I constructed components designed to help participants generate and demonstrate sociopolitical art understandings during studio art critiques. One component of this critique concerns what is said: it is the introduction and reinforcement of critical strategies through the frequent use of a list of questions. Another component concerns who does the talking about what, and in what manner; it focuses on the structure of the class discussions, and the ways students and the instructor are organized during discussions.

\section{The guiding list of questions}

The list of questions was printed on a sheet of paper that was given to each student. Students brought the sheet to all critiques and were frequently asked to consider the questions on the sheet throughout the quarter. Students were asked to consider whether any of the questions might inform their critical understandings of artworks discussed during critiques. Students understood that they should consider the questions, and that the questions may or may not be particularly informative in guiding their understandings of the artworks. The first questions are critical procedures; other questions focused on differing sociopolitical concerns. The questions were as follows:

Describe and interpret the artwork. Consider the following questions.

1. What feelings do you have about it? Why do you have those feelings?

2. What does the artwork say about wornen? 
3. What does the artwork say about men?

4. What does the artwork say about race?

5. What does the artwork say about class, sexual orientation, age, ethnicity or other factors?

6. How has your identity influenced your view of the artwork?

7. How do you think the artist's identity influenced the artwork?

8. What kinds of ideas about life does the artwork prompt you to think about?

9. What does the artwork make you think about photography, about ant, about art making and the art world?

10. Are there other kinds of information that may be particularly useful in understanding this artwork?

11. What kinds of information might this be and how might you find it? Should you try to?

12. What function does the artwork have in society?

13. What function does this artwork have for the artist?

14. Evaluate the artwork.

15. What is/are your criteria for judgment?

Students, usually in small groups, were often asked to choose one question to augment the classroom discussion of artworks. The questions were designed to be a springboard for opening up discussions of a sociopolitical nature. These kinds of questions were not the only ones students were asked to consider during critiques. Questions that address technical and formal concerns were also included in all critical discussions.

\section{Group structure}

Some feminist theorists imply that the way that students are organized in educational settings has implications for enhancing feminist ideas. Bell hooks (1994) states that "making the classroom a democratic setting where everyone feels a responsibility to contribute is a central goal of transformative pedagogy" ( $p$. 39), and that

One of my teaching strategies is to redirect their attention away from my voice to one another's voices. I often find that this happens most quickly when students share experiences in conjunction with academic subject matter" (p. 151).

Garber (1992b) states that

We must be prepared to give up some of our power. As teachers, we must no longer desire to be the masters of the discourse. (p. 27)

Students mostly discussed artworks in small groups, and all students were encouraged to contribute to discussions in small groups. Throughout the quarter, students were given more and more responsibility for what happened during the critique. As the end of the quarter neared, small groups of students had almost complete responsibility for leading critical discussions about artworks. Sustained, student-initiated and student-led dialogue that demonstrates 
understandings about sociopolitical meanings of artworks is the goal of this critique.

\section{Analysis}

This study centers around the concept, "sociopolitical ant understandings," which, in this study, refers to ideas concerning social and political issues about life and art that arise from participants' discussions of artworks. I read through transcript of the dialogue that took place during critiques and developed categories and codes with which I might analyze the data.

First, I coded for kinds of critical procedures that were demonstrated, because explorations of sociopolitical meanings are interpretive by nature. Then, I developed a numerical rating scale from one to five for students' sociopoliticallyfocused comments and discussions. What I rated is the participants' engagement with, the depth with which sociopolitical issues were explored, regardless of the kind of sociopolitical content of their comments.

A minimum qualifying example occurred during the discussion of a portrait of a woman who is smiling broadly. One male student stated that the photograph appeared to counter "lots of stereotyped things that you hear, like wornen are unapproachable." This statement qualifies as a very low level sociopolitical comment because the participant has gone beyond simply identifying a topic ('women') that is potentially rich in sociopolitical meaning and has begun to minimally explore at least one idea associated with that category, in this case, stereotypes associated with women.

While students may become engaged in discussing sociopolitical aspects of images, the results may or may not end in discussions that I would interpret as positive or as having what I will term "reconstructive potential." Reconstructive potential refers to discussions that reveal either oppressive or positive aspects of society, ideas that are reconstructive of society. I would be presumptuous to assume that I could know what is repressive or what is positive for various peoples and in terms of various social issues. However, there are ideas that many ferninists in particular, as well as others, would agree that are probably repressive or probably liberating or which have reconstructive potential, at least to some degree. In the forward to an anthology, Maxine Greene refers to the array of ferninist perspectives in the book, stating that:

All, committed as they are to identifying an emancipatory feminist praxis, cannot but work to clarify what it signifies to "empower" and what, given the institutions in which feminist teaching must take place, empowerment may imply in specific contexts. (Greene, p. x, in Luke and Gore, 1992).

An example of a comment with minimally qualifying reconstructive potential occurred when one participant discussing the image of a well-toned fernale dancer, said 
She looks like her looks are really powerful and striking.... Plus her body is really muscled, well-defined. So this might say something about women, 100.

In this example, what the image may be saying about women is mostly undeveloped. However, the implication of this student's comment is that depicting a powerful and physically strong woman might have been done to counter or make a point about how women are often depicted. Additionally, the student's phrasing reinforces this image as a legitimate and positive way of depicting women.

I coded sociopolitical art understandings, then, in two ways. The first indicates the extent of student's engagement with social and political issues as they relate to artworks discussed in the critiques. The second aspect of coding concerns whether or not those explorations have what I will term reconstructive potential. In other words, a participant could demonstrate sustained engagement with sociopolitical aspects of an image, yet those ideas could simply reinforce what is considered by many feminists and others to be negatively stereotypical.

Another aspect of a feminist studio art critique concerns additional ways that the instructor can further students' explorations of sociopolitical art understandings when it seems appropriate and meaningful to do so. The kind of situation in which it is appropriate and meaningful to do so occurs when students' comments and student-led discussions appear to need further momentum and/or direction in order to better explore sociopoltical ideas that relate to student artworks. Although the goal of this critique is for students to independently lead sustained sociopolitically-focused discussions of artworks, the role of the instructor is to sometimes augment and refocus discussions. I will term these instances as "instructor nudges." An example of an instructor nudge was demonstrated when students were discussing a photograph depicting the sign and storefront of a feminist bookstore, and trying to determine what point of view concerning the bookstore or feminism in general the image reflected. One male student stated.

I think it's not so ambiguous considering that we know the sex of the artist. That it's going to be more against than for it. I know Martin and he doesn't look like the militant feminist type.

In response to this the instructor intervened and asked that a specific sociopolitical aspect of the student's comment be addressed. The issue of who and what a feminist is and whether men can be feminists is an important one. The instructor requested a response, asking "because he's a man does that mean that this is an anti-feminist statement?"

Views about sociopolitical topics are obviously subjective. Another feminist instructor involved in a feminist studio ant critique, for example, who does not believe that men can be feminists may not have nudged the discussion further, or may have nudged it to encourage a continuation of the discussion no matter what the outcome. 


\section{Results}

This study represents a beginning rather than an end. It is a tentative study since the sample size is small. The information presented here should be understood to be a series of suggestions and ideas that will almost certainly be modified under different circumstances. The major strength of this project is that it represents a series of interventions that happened over the duration of a course. Therefore, the study is realistic about how change might be instituted: in increments, through sustained activities over long periods of time.

An important finding is that ferninist ideas can be used successfully by everyone to enhance sociopolitical art understandings. All members of the class, men and women alike, used feminist ideas to discuss sociopolitical aspects of student artworks during studio art critiques. Since feminism is increasingly broadening, and now encompasses many concerns in addition to gender, and since many feminist theorists insist upon an ongoing critique of these theories, ferninist ideas are more useful than ever in the studio art critique and other situations.

Another finding is that students are capable of discussing sociopolitical aspects of images with sensitivity, depth and thoroughness. Participants sometimes demonstrated extended engagement with sociopolitical art understandings throughout the course. At times students thoughtfully explored how identity-based constructs can influence art understandings during studio art critiques. A related finding is that students exploring issues about identity demonstrated some understanding of the complexity of identity-based constructs. The critiques also raised many non-identity-based sociopolitical issues. Topics discussed during critiques included motherhood, smoking, violence, fatherhood, and women in the media.

Another finding is that sociopolitical discussions can be encouraged by a nudge from the instructor to keep directing thinking about sociopolitical issues as they relate to artworks. A good example occurred when students were discussing the image of a dancer the discussion was nudged further. Students were asked to consider depictions of women in popular culture to prompt them to explore their reactions to the image. Instructors should be encouraged to nudge discussions in order to further encourage the exploration of sociopolitical ideas.

Another finding is that students value the variety of interpretations and world views shared by classmates during critiques. At the beginning of the Documentary Critique, students mentioned that they valued the views of other students and felt that they benefited the most from critiques when varying ideas were heard. This bodes well for criticism as it is advocated by many art educators and many feminist arl educators in particular.

An important finding is that students tend to neglect and to doubt the importance of descriptive activities during studio art critiques. Instructors need to include descriptive activities in studio art critiques. Students' tendency is to 
assume that description is superfluous since usually everyone is simultaneously looking at the same image during critique.

Another finding is that students are capable of sustained student-led critical discussions about artworks. A gradual shift of responsibility from instructorled discussions to mostly student-led discussions throughout a course is advocated.

Another finding is that an instrument such as the Guide Sheet of Questions can contribute to students' sociopolitical art understandings during studio art critiques. Although students can be verbally prompled, they can forget, especially during small group discussions. The sheet provided a tool that participants continually referred to. Additionally, the specificity of the questions at times prompted specific sociopolitical directions of thought.

Another important finding is that although an instrument such as the Guide Sheet of Questions can contribute to students' sociopolitical art understandings during studio art critiques, it can also become tedious or seem too prescriptive to students. On several occasions, some students used the Guide Sheet of Questions with reluctance and apathy. I advocate using such instruments sensibly and sparingly, and to consider using a collaborative process between students and instructor in creating them. Additionally I encourage the development of other kinds of sociopolitically-focused instruments to be used in critiques

Another important finding is that many of the ideas associated with the construct known as "the studio art critique" that students are likely to have been exposed 10, are a formidable stumbling block to the goals of a feminist studio art critique. Among the undesirable ideas often associated with studio ant critiques are that the instructor and/or the artist are the true authorities on artworks, that critiques should not focus on meanings of artworks but instead on expressive, formal and/or technical issues, that critiques are not important and therefore should be succinct, and that considerations of sociopolitical ideas in relation to the artworks are irrelevant and extraneous.

Another finding is that student-led sociopolitical discussions about artworks can be enhanced by classroom structures such as small-group discussion. This provides an opportunity for many students to articulate their views, and allows more time for discussion in intimate situations before discussing images as a large group.

Another finding is that studio art critiques in which sociopolitical aspect of artworks are discussed are likely to take more time than typical studio ant critiques. One recommendation is to allow more time for critiques. Another is reserving less in-class time to artistic production. Another way to allow for more time is by perhaps reducing the number of artworks a student produces over the span of an art course. 
Another finding is that an overtly sociopolitical art assignment is likely to lead to artworks and discussions during critiques that are clearly and purposefully sociopolitical. I recommend that instructors give significant consideration to the sociopolitical implications of studio art projects and consider the possibility of including some overtly sociopolitically-focused ant projects.

Some recommendations for future studies include the need to explore different interpretations of feminist ideas as they apply to the studio art classroom and especially to studio art critiques. Further studies that investigate different ways to reinforce an emphasis on sociopolitical aspects of artworks are also recornmended. Further studies should be conducted concerning ways in which written critical activities might be interspersed with dialogue in ways that enhance sociopolitical art understandings. Further study is needed to explore ways in which different kinds of classroom structures for discussion can affect sociopolitical ant understandings. Further study is needed to determine ways in which to counter undesirable ideas often associated with studio art critiques that oppose the goals of a ferninist studio art critique, including methods for dissuading students from valuing intentionalist-based studio art critiques.

Additionally, I recommend future studies that explore ways to facilitate descriptive activities during studio ant critiques.

\section{References}

Barrett, T. (1988). A comparison of the goals of studio art professors conducting critiques and art education goals for teaching criticism. Studies in Art Education, 30(1), 22-27.

Barrett, T. (1994a). Principles for interpreting art. Art Education, 47(5), 8-13.

Barrett, T. (1994b). Criticizing Art. Mountain View, CA: Maytield.

Bright, D. (1988). Confusing my students, eating my words*. Expos ure, $26(1), 14-18$.

Bryson, V. (1992). Feminist political theory. New York: Paragon.

Congdon, K.G. (1991). Ferninist approaches to art criticism. In D. Blandy and K.G. Congdon (Eds.), Pluralistic approaches to art criticism, pp. 15-23. Bowling Green, $\mathrm{OH}$ : Bowling Green State University Popular Press.

Garber, E. (1990). Implications of ferninist art criticism for art education. Studies in Art Education, 32(1), 17-26.

Garber, E. (1992a). Feminism, aesthetics, and art education. Studies in Art Education, 33(4), 210-225. 
Garber, E. (1992b). Object into subject: Feminism, art, education, and the construction of the self. Canadian Review of A rt Education, $19(1), 12-31$.

Greene, M. (1992). Foreword. In Carmen, L. \& Gore, J. (Eds.), Feminisms and critical pedagogy, (pp. ix-xi). New York: Routledge.

Hagaman, S. (1990). Feminist inquiry in art history, art criticism, and aesthetics: An overview for art education. Studies in Art Education, 32(1), 27-35.

Hamblen, K. (1986). Three areas of concern for art criticism instruction: Theoretical and research foundations, sociological relationships, and teaching methodologies. Studies in Art Education, 27(4), pp. 163-173.

Harding, S. (1993). Reinventing ourselves as other: More new agents of history and knowledge. In L. Kauffman (Ed.), American feminist thought at century's end: A reader. (pp. 140-164).

Hennessy, R. (1993). Materialist feminism and the politics of discourse. New York: Routledge.

hooks, b. (1994). Teaching to transgress. New York: Routledge.

Humm, M. (1992). History of feminism in Britain and America. In M. Humm (Ed.). Modern feminisms. (pp. 1-4). New York: Columbia University Press.

Jaggar, A. (1988). Feminist politics and human nature. New Jersey: Rowman and Littlefield.

Lather, P. (1992). Critical frames in educational research: Feminist and poststructural perspectives. Theory into Practice, 31(2), 87-99.

Nadaner, D. (1994). Critique and intervention: Implications of social theory for art education. Studies in Art Education, 26(1), 20-26.

Pollock, G. (1987). Feminism and modernism. In R. Parker \& G. Pollock (Eds.), Framing feminism: Art and the women's movement 19701985 .

Tong, R. (1989). Feminist thought. Boulder and San Francisco: Westview Press.

Walby, S. (1990). Theorizing patriarchy. Oxford and Cambridge: Basil Blackwell.

Weed, E. (1989). (Ed). Introduction: Terms of reference. Coming to terms: Feminism, theory, politics. (pp. ix-xxxi). New York: Routledge.

Marilyn Zurmuehlen's Working Papers In Art Education 1996-1997 